\title{
A New Antiherpetic Agent Produced by Streptomyces sp. Strain No. 758
}

\author{
Masaru Uyeda ${ }^{* \dagger}$, Ken-ICHIROU KONDO $^{\dagger}$, AKIo Ito ${ }^{\dagger}$, \\ KazUMi YoKomizo ${ }^{\dagger}$ and YUTAKa KIDo ${ }^{\dagger \dagger}$ \\ Faculty of Pharmaceutical Sciences ${ }^{\dagger}$ and Center of Instrumental Analyses ${ }^{\dagger \dagger}$, Kumamoto University, \\ 5-1 Oe-Honmachi, Kumamoto 862, Japan \\ (Received for publication May 15, 1995)

\begin{abstract}
A new antiherpetic agent, AH-758, was isolated from the culture broth of Streptomyces sp. strain No. 758. The structure was determined by NMR spectral analyses to be a new antibiotic belonging to bafilomycin group containing (5-oxo-2-pyrrolin-2-yl) methyl fumarate in its C-21.
\end{abstract}

In the course of our screening program for the antiherpetic agents from soil microorganisms, a new antiherpetic agent has been isolated from Streptomyces sp. strain No. 758 and was named AH-758. From the structural elucidation, it was concluded that $\mathrm{AH}-758$ was a new 16-membered macrolide antibiotic belonging to bafilomycin group. However, it remarkably differed in a substituent in the $\mathrm{C}-21$ side chain from bafilomycins. AH-758 inhibited viral proliferation in infected Vero cell culture, and $50 \%$ effective concentration $\left(\mathrm{EC}_{50}\right)$ of AH-758 was $0.09 \mu \mathrm{g} / \mathrm{ml}$. While, $50 \%$ inhibitory concentration $\left(\mathrm{IC}_{50}\right)$ of the compound was $1.3 \mu \mathrm{g} / \mathrm{ml}$ against the cell growth. In addition, AH-758 showed strong antifungal activity and weak antibacterial activity. In this paper, we described the taxonomy, fermentation, purification, chemical structure, physical and biological properties of $\mathrm{AH}-758$.

\section{Materials and Methods}

Microorganisms and Cells

The producing organism, strain No. 758 was isolated from a soil sample collected in Kumamoto City, Kumamoto, Japan. Streptomyces rochei IFO 12908 was used as type strain. Test organisms for antimicrobial activity were obtained from IFO.

Herpes simplex virus type 1 strain KOS and Vero cells were provided by the Chemo-Sero-Therapeutic Institute.

Taxonómic Studies

Cultural and physiological characteristics were determined by the methods of SHIRLING and GotTLIEB ${ }^{1)}$, and WAKSMAN $^{2)}$. Carbohydrate utilization was investigated by using the procedure of PrIDHAM and GotTLIEB ${ }^{3)}$.

\section{Biological Assay}

The antiviral and anticellular activities of AH-758 were measured by the plaque reduction assay ${ }^{4)}$ and cell growth inhibition test ${ }^{5)}$. Confluent monolayers of Vero cells $\left(1 \times 10^{6}\right.$ cells $)$ in 6 -well plastic plates $(35 \mathrm{~mm}$ diameter $)$ were infected with $100 \mathrm{PFU}$ of $\mathrm{HSV}-1$ (KOS). After 1 hour adsorption period at $37^{\circ} \mathrm{C}$, the cultures were overlaid with $2 \mathrm{ml}$ of DuLBECCo's modified Eagle minimum essential medium (DMEM) containing 2\% heat-inactivated fetal calf serum and various concentrations of drugs. The cultures infected with HSV-1 were incubated in the $\mathrm{CO}_{2}$ incubator, and fixed with formalin and stained with crystal violet in methanol at 3 days after infection.

Cell growth inhibition test was examined as described below. Vero cells were seeded in 6-well plastic plates at $1 \times 10^{6}$ cells per well. After 1 day, the cells were refed with DMEM containing 5\% fetal calf serum and various concentrations of drugs. After incubation for 3 days, cells were dispersed by treatment with trypsin, and viable cell numbers were counted.

Waksman's agar dilution streak method was used for the determination of the antimicrobial spectrum of AH-758.

\section{Fermentation Studies}

Strain No. 758 was cultured for 2 days at $28^{\circ} \mathrm{C}$ in a medium $(50 \mathrm{ml}$ in a $200-\mathrm{ml}$ Erlenmeyer flask with one intrusion) consisting of glucose $2.0 \%$, starch $3.0 \%$, C.S.L. $1.0 \%$, S.B.F. $1.0 \%$, peptone $0.5 \%, \mathrm{NaCl} 0.3 \%$, $\mathrm{CaCO}_{3} 0.3 \%, \mathrm{pH} 7.2$. These cultures were used as inoculum for 10-liter fermentor and cultivated under the following cultural conditions: $4 \%$ inoculum was transferred to a 10-liter fermentor containing 5 liters medium consisting of glucose $5.0 \%$, peptone $1.0 \%$, meat extract $0.5 \%, \mathrm{NaCl} 0.3 \%, \mathrm{CaCO}_{3} 0.3 \%, \mathrm{pH} 7.2$ and run at $28^{\circ} \mathrm{C}$ for 3 days with $350 \mathrm{rpm}$ agitation and 4 liter/ minute aeration.

\section{Analytical Procedures}

MP was determined with a Yanagimoto melting point apparatus. UV absorption spectrum was measured in methanol with a Hitachi U-2000 spectrophotometer. Optical rotation was determined on a Jasco DIP-360 digital polarimeter. The IR spectrum was taken in $\mathrm{KBr}$ tablets on a Jeol JIR-6500W infrared spectrophotometer. 
Table 1. Cultural characteristics of strain No. 758.

\begin{tabular}{|c|c|c|c|}
\hline Medium & Growth & Aerial mycelium & Soluble pigment \\
\hline $\begin{array}{l}\text { Sucrose-nitrate agar } \\
\text { (Czapek's soln. agar) }\end{array}$ & Poor & None & None \\
\hline $\begin{array}{l}\text { Glucose-asparagine } \\
\text { agar }\end{array}$ & Excellent & Excellent, birch & None \\
\hline $\begin{array}{l}\text { Glycerol-asparagine } \\
\text { agar (ISP No. 5) }\end{array}$ & Excellent & Excellent, pinkish & None \\
\hline Calcium malate agar & Good & Moderate, light gray & None \\
\hline Nutrient agar & Good & None & None \\
\hline $\begin{array}{l}\text { Yeast ext.-malt ext. } \\
\text { agar (ISP No. 2) }\end{array}$ & Excellent & $\begin{array}{l}\text { Excellent, fawn to } \\
\text { beaver }\end{array}$ & None \\
\hline $\begin{array}{l}\text { Oatmeal agar } \\
\text { (ISP No. 3) }\end{array}$ & Moderate & Scant & None \\
\hline $\begin{array}{l}\text { Inorganic salts-starch } \\
\text { agar (ISP No. 4) }\end{array}$ & Good & Good, birch & None \\
\hline $\begin{array}{l}\text { Tyrosine agar } \\
\text { (ISP No. } 7 \text { ) }\end{array}$ & Excellent & Excellent, birch & None \\
\hline
\end{tabular}

Table 2. Comparison of taxonomic characteristics of strain No. 758 with Streptomyces rochei.

\begin{tabular}{|c|c|c|}
\hline & No. 758 & $\begin{array}{l}\text { Streptomyces rochei } \\
\text { IFO } 12908 \\
\end{array}$ \\
\hline Spore chain morphology & Spiral & Spiral \\
\hline Spore surface & Smooth & Smooth \\
\hline Aerial mass color & Gray & Gray \\
\hline Soluble pigment & - & - \\
\hline Formation of melanoid pigment & - & - \\
\hline $\begin{array}{l}\text { Liquefaction of glucose } \\
\text { peptone gelatin }\end{array}$ & - & - \\
\hline Coagulation of milk & - & - \\
\hline Peptonization of milk & + & + \\
\hline Hydrolysis of starch & - & + \\
\hline \multicolumn{3}{|l|}{ Utilization of } \\
\hline L-Arabinose & + & + \\
\hline D-Fructose & + & + \\
\hline D-Glucose & + & + \\
\hline Inositol & + & + \\
\hline D-Mannitol & + & + \\
\hline Raffinose & - & - \\
\hline Rhamnose & \pm & $\pm \sim(+)$ \\
\hline Sucrose & - & - \\
\hline D-Xylose & + & + \\
\hline
\end{tabular}

+ , positive; - , negative; \pm , doubtful. 
Mass spectra were measured with a Jeol JMS-DX303HF MS spectrometer. ${ }^{1} \mathrm{H}$ NMR, ${ }^{13} \mathrm{C}$ NMR,${ }^{1} \mathrm{H}^{-1} \mathrm{H}$ COSY, and ${ }^{1} \mathrm{H}^{-13} \mathrm{C} C O S Y$ spectra with TMS as internal standard were taken in methanol- $d_{4}$ at $400 \mathrm{MHz}$ on a Jeol JMNGX400 spectrometers.

\section{Results and Discussion}

\section{Taxonomy}

Strain No. 758 was isolated from a soil sample collected in Kumamoto City, Japan. Taxonomical characterization was carried out according to the method of International Streptomyces Project (ISP). The cultural characteristics of strain No. 758 grown on various media at $28^{\circ} \mathrm{C}$ for 14 days are shown in Table 1 . The growth was good on various media, but poor on sucrose - nitrate agar. Soluble pigments were not produced in all agar media. Strain No. 758 grew well at the range of 28 to $37^{\circ} \mathrm{C}$ with optinum temperature at $37^{\circ} \mathrm{C}$ on glycerolasparagine agar, but not below $14^{\circ} \mathrm{C}$ and over $50^{\circ} \mathrm{C}$. Formation of melanoid pigment, liquefaction of gelatin, coagulation of milk, hydrolysis of starch, decomposition of cellulose were negative, but peptonization of milk was positive. Comparison of characteristics of strain No. 758 with those of Streptomyces species described by SHIRING $^{11}$, WAKSMAN $^{2)}$ and BERGEY ${ }^{6)}$ indicated that strain No. 758 closely resembled Streptomyces rochei. The comparison of both strains is summarized in Table 2 . The physiological properties of Streptomyces rochei were similar to the strain No. 758 except for hydrolysis of starch. Therefore strain No. 758 was identified as a strain belonging to Streptomyces rochei.

\section{Isolation}

The production of AH-758 started in the logarithmic growing phase and increased with the growth of the mycelium. The antiherpetic activity reached maxinum after 3 days of cultivation and gradually decreased thereafter.

Isolation of AH-758 was carried out by monitoring the antiherpetic activity. Culture filtrate ( $c a .5$ liters) of strain No. 758 was adsorbed batchwisely on Diaion HP-10 for 12 hours. After washing with $80 \% \mathrm{MeOH}$, AH-758 was eluted with $100 \% \mathrm{MeOH}$. The active fractions were pooled and concentrated in vacuo to form an oily material, which was dissolved in a small volume of $\mathrm{CHCl}_{3}$, and applied to a silica gel column. AH-758 was eluted with a mixture of $\mathrm{CHCl}_{3}-\mathrm{Me}_{2} \mathrm{CO}-\mathrm{MeOH}$ $(8: 1: 0.5)$. The fractions containing $\mathrm{AH}-758$ were pooled and concentrated in vacuo to form crude yellow powder, which was dissolved in a small volume of $\mathrm{CHCl}_{3}$ and applied to a Sephadex LH-20 column. The chromatography was developed with $\mathrm{CHCl}_{3}$ and the active fractions were pooled and concentrated in vacuo. Yield of AH-758 was $10 \mathrm{mg}$ from 5 liters of the culture filtrate.

\section{Physico-chemical Properties}

Physico-chemical properties of AH-758 are shown in Table 3. AH-758 was obtained as yellow green powder with $\mathrm{MP}$ at $128 \sim 130^{\circ} \mathrm{C}$. It was readily soluble in $\mathrm{Me}_{2} \mathrm{CO}$, $\mathrm{MeOH}$ and $\mathrm{CHCl}_{3}$ but insoluble in water. The UV absorption maxima of $\mathrm{AH}-758$ in $\mathrm{MeOH}$ were observed at 249 ( $\varepsilon 38,100$ ), 285 (shoulder; $\varepsilon 16,300$ ) and $350 \mathrm{~nm}$ (shoulder; $\varepsilon 3,200$ ). It showed IR absorptions at 3425 , 3251,2873 and $1722 \mathrm{~cm}^{-1}$ due to hydroxyl, amino, methoxy and carbonyl groups, respectively. The EI-MS of AH-758 showed several intensive fragment ion peaks up to $m / z 568$, but no molecular ion peak. The elementary analysis of AH-758 afforded $\mathrm{C}_{45} \mathrm{H}_{67} \mathrm{NO}_{13}$ as molecular formula, which agreed with the $m / z 828(\mathrm{M}-\mathrm{H})^{-}$as negative ion peak and $m / z 852(\mathrm{M}+\mathrm{Na})^{+}$as positive ion peak on the FAB-MS. The molecular formula was also supported by the ${ }^{1} \mathrm{H}$ NMR (Fig. 1) and ${ }^{13} \mathrm{C}$ NMR (Fig. 2) spectral data, which were summarized in Table 4 . The ${ }^{13} \mathrm{C}$ NMR spectrum of AH-758 showed the 45 carbons. The analysis of DEPT spectrum indicated that AH-758 consisted of the following functional groups: $\mathrm{CH}_{3} \times 9$, $\mathrm{CH}_{2} \times 3, \mathrm{CH} \times 6, \mathrm{OCH}_{3} \times 3, \mathrm{CH}_{2}-\mathrm{O} \times 1, \mathrm{CH}-\mathrm{O} \times 6$, $\mathrm{O}-\mathrm{C}-\mathrm{O} \times 1, \mathrm{CH}=\times 8, \mathrm{C}=\times 4, \mathrm{C}=\mathrm{O} \times 4$.

Structural Elucidation

Partial structures I, II, III, IV, V and VI (Fig. 3) were deduced from the ${ }^{1} \mathrm{H}^{-1} \mathrm{H}$ COSY and ${ }^{1} \mathrm{H}^{-1}{ }^{13} \mathrm{C}$ COSY spectra. The partial structure I was deduced by the correlation from the signal at $\delta_{\mathrm{H}} 3.26(\mathrm{H}-7)$ through $\delta_{\mathrm{H}}$ $2.50(\mathrm{H}-6)$ to $\delta_{\mathrm{H}} 5.88(\mathrm{H}-5), 1.07(27-\mathrm{H})$, and through $\delta_{\mathrm{H}}$ $1.84(\mathrm{H}-8)$ to $\delta_{\mathrm{H}} 2.02(\mathrm{H}-9), 0.92(28-\mathrm{H})$ in the ${ }^{1} \mathrm{H}^{1}{ }^{1} \mathrm{H}$

Table 3. Physico-chemical properties of AH-758.

\begin{tabular}{|c|c|}
\hline Nature & Yellow green powder \\
\hline $\begin{array}{l}\mathrm{MP}\left({ }^{\circ} \mathrm{C}\right) \\
{[\alpha]_{\mathrm{D}}^{25}(\mathrm{c} 0.1, \mathrm{MeOH})}\end{array}$ & $\begin{array}{l}128 \sim 130 \\
+24.4^{\circ}\end{array}$ \\
\hline FAB-MS (m/z) & $852(\mathrm{M}+\mathrm{Na})^{\dagger}, 828(\mathrm{M}-\mathrm{H})$ \\
\hline Molecular formula & $\mathrm{C}_{45} \mathrm{H}_{67} \mathrm{NO}_{13}$ \\
\hline $\mathrm{UV} \lambda_{\max }^{\mathrm{MeOH}} \mathrm{nm}(\varepsilon)$ & $\begin{array}{l}249(38,100) \\
285(\text { sh, 16,300) } \\
350(\text { sh, } 3,200)\end{array}$ \\
\hline $\mathrm{IR} v \max (\mathrm{KBr}) \mathrm{cm}^{-1}$ & $\begin{array}{l}3425,3251,2873,1722 \\
1689\end{array}$ \\
\hline \multicolumn{2}{|l|}{ Solubility } \\
\hline $\begin{array}{l}\text { Soluble } \\
\text { Insoluble }\end{array}$ & $\begin{array}{l}\mathrm{Me}_{2} \mathrm{CO}, \mathrm{MeOH}, \mathrm{CHCl}_{3} \\
\mathrm{H}_{2} \mathrm{O}\end{array}$ \\
\hline
\end{tabular}


Fig. 1. ${ }^{1} \mathrm{H}$ NMR spectrum of $\mathrm{AH}-758$ in $\mathrm{CD}_{3} \mathrm{OD}(400 \mathrm{MHz})$.

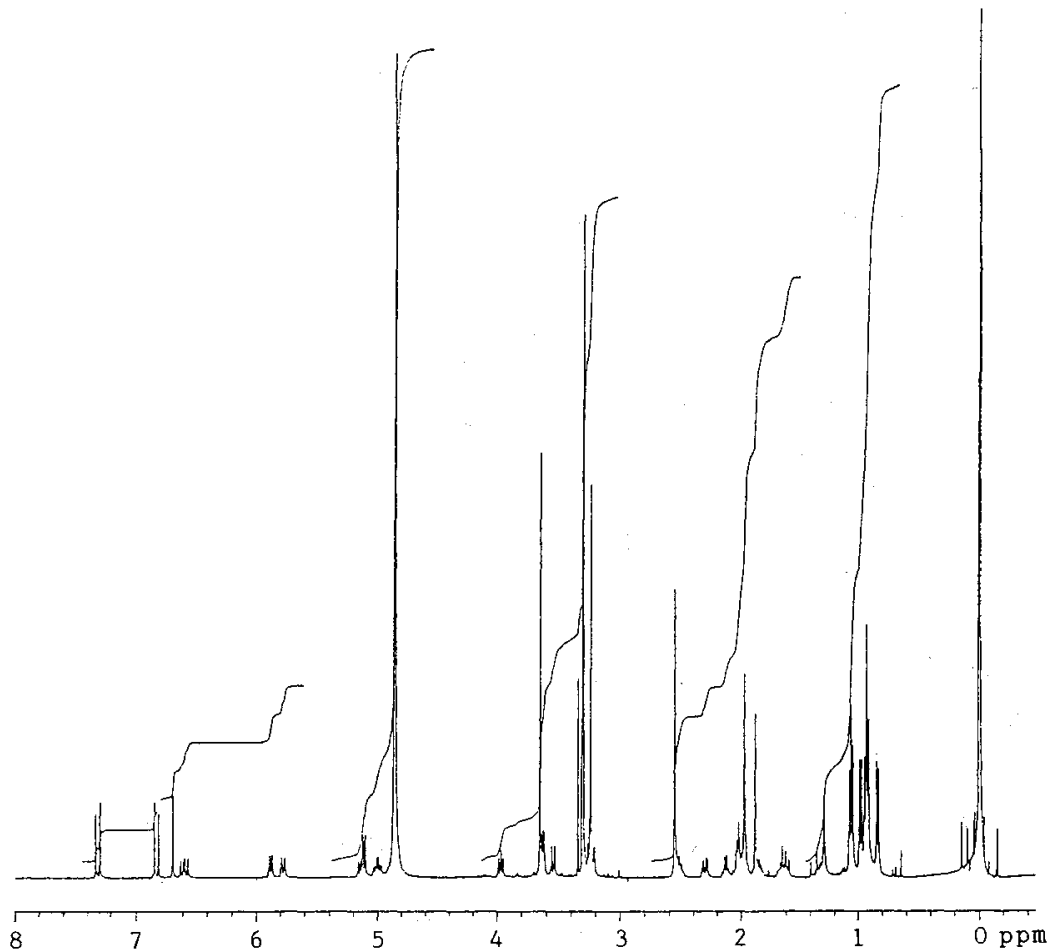

Fig. 2. ${ }^{13} \mathrm{C}$ NMR spectrum of $\mathrm{AH}-758$ in $\mathrm{CD}_{3} \mathrm{OD}(400 \mathrm{MHz})$.

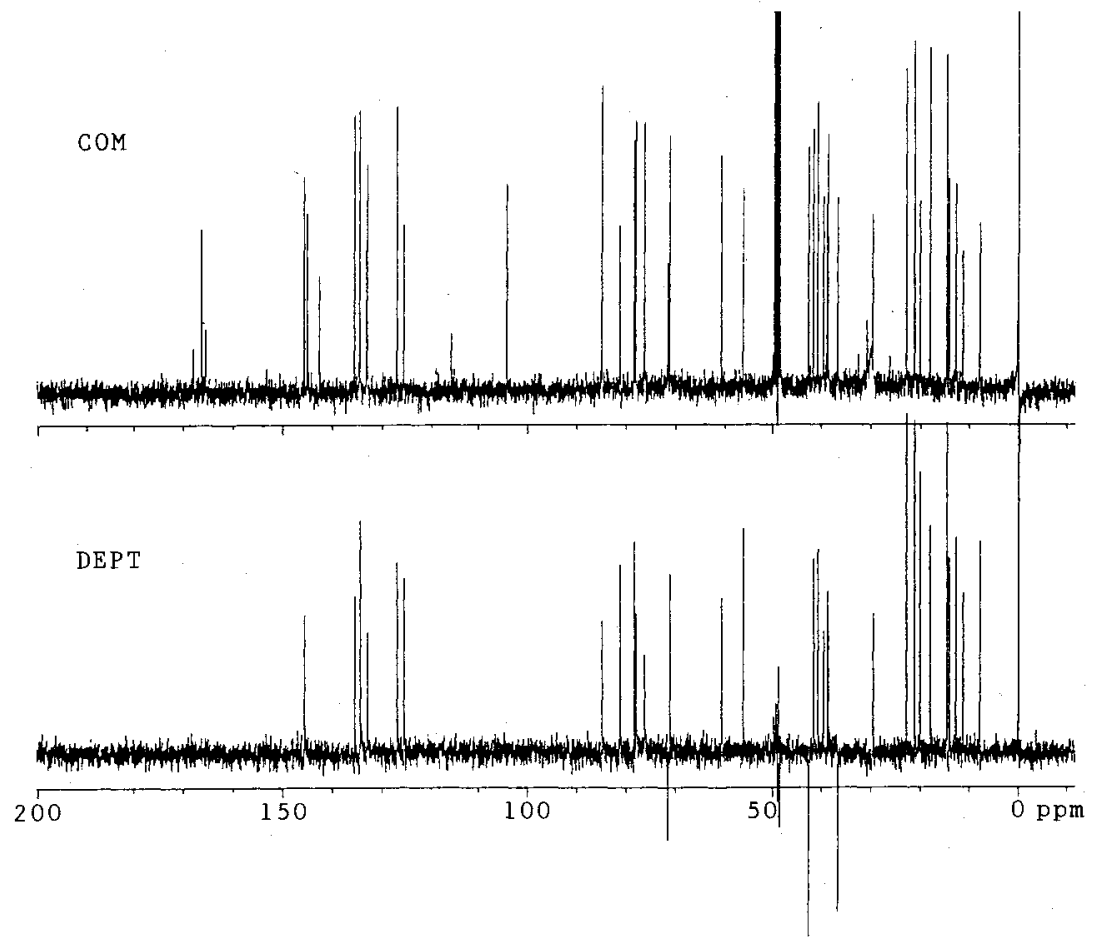

COSY spectrum. The partial structure II was deduced by the correlation from the olefinic proton at $\delta_{\mathrm{H}} 5.15$ $(\mathrm{H}-13)$ through $\delta_{\mathrm{H}} 3.97(\mathrm{H}-14)$ to $\delta_{\mathrm{H}} 5.11(\mathrm{H}-15)$, and through the olefinic proton at $\delta_{\mathrm{H}} 6.59(\mathrm{H}-12)$ to $\delta_{\mathrm{H}} 5.77$ $(\mathrm{H}-11)$. The partial structure III was deduced by the correlation from the signal at $\delta_{\mathrm{H}} 3.21(\mathrm{H}-17)$ through $\delta_{\mathrm{H}}$ $2.13(\mathrm{H}-16)$ to $\delta_{\mathrm{H}} 0.98(30-\mathrm{H})$, and through $\delta_{\mathrm{H}} 1.60(\mathrm{H}-18)$ to $\delta_{\mathrm{H}} 0.84(31-\mathrm{H})$. The partial structure IV was deduced by the correlation from the signal at $\delta_{\mathrm{H}} 3.55(\mathrm{H}-23)$ through $\delta_{\mathrm{H}} 2.02(\mathrm{H}-22)$ to $\delta_{\mathrm{H}} 0.94(32-\mathrm{H}), 4.98(21-\mathrm{H})$ 
Table 4. NMR spectral data for $\mathrm{AH}-758$ in $\mathrm{CD}_{3} \mathrm{OD}$.

\begin{tabular}{cccccc}
\hline Position & $\delta \mathrm{C}$ & $\delta \mathrm{H}$ & Position & $\delta \mathrm{c}$ & $\delta \mathrm{H}$ \\
\hline 1 & $168.0(\mathrm{~s})$ & - & 23 & $71.1(\mathrm{~d})$ & $3.55(\mathrm{~d}, \mathrm{~J}=10.3,1 \mathrm{H})$ \\
2 & $142.5(\mathrm{~s})$ & - & 24 & $29.6(\mathrm{~d})$ & $2.02(\mathrm{~m}, 1 \mathrm{H})$ \\
3 & $134.6(\mathrm{~d})$ & $6.69(\mathrm{~s}, 1 \mathrm{H})$ & 25 & $11.3(\mathrm{q})$ & $0.92(\mathrm{~d}, \mathrm{~J}=6.96,3 \mathrm{H})$ \\
4 & $133.2(\mathrm{~s})$ & - & 26 & $14.1(\mathrm{q})$ & $1.97(\mathrm{~d}, \mathrm{~J}=0.73,3 \mathrm{H})$ \\
5 & $145.5(\mathrm{~d})$ & $5.88(\mathrm{~d}, \mathrm{~J}=9.16,1 \mathrm{H})$ & 27 & $18.0(\mathrm{q})$ & $1.07(\mathrm{~d}, \mathrm{~J}=5.50,3 \mathrm{H})$ \\
6 & $38.6(\mathrm{~d})$ & $2.50(\mathrm{~m}, 1 \mathrm{H})$ & 28 & $14.5(\mathrm{q})$ & $0.92(\mathrm{~d}, \mathrm{~J}=5.13,3 \mathrm{H})$ \\
7 & $81.2(\mathrm{~d})$ & $3.26(\mathrm{~m}, 1 \mathrm{H})$ & 29 & $20.0(\mathrm{q})$ & $1.88(\mathrm{~s}, 3 \mathrm{H})$ \\
8 & $41.6(\mathrm{~d})$ & $1.84(\mathrm{~m}, 1 \mathrm{H})$ & 30 & $7.8(\mathrm{q})$ & $0.98(\mathrm{~d}, \mathrm{~J}=6.96,3 \mathrm{H})$ \\
9 & $42.6(\mathrm{t})$ & $2.02(\mathrm{~m}, 2 \mathrm{H})$ & 31 & $12.7(\mathrm{q})$ & $0.84(\mathrm{~d}, \mathrm{~J}=6.60,3 \mathrm{H})$ \\
10 & $144.9(\mathrm{~s})$ & - & 32 & $22.7(\mathrm{q})$ & $0.94(\mathrm{~d}, \mathrm{~J}=7.33,3 \mathrm{H})$ \\
11 & $125.6(\mathrm{~d})$ & $5.77(\mathrm{~d}, \mathrm{~J}=10.6,1 \mathrm{H})$ & 33 & $21.1(\mathrm{q})$ & $1.05(\mathrm{~d}, \mathrm{~J}=6.96,3 \mathrm{H})$ \\
12 & $135.6(\mathrm{~d})$ & $6.59(\mathrm{dd}, \mathrm{J}=10.6,15.6,1 \mathrm{H})$ & $1^{\prime}$ & $166.2(\mathrm{~s})$ & - \\
13 & $127.0(\mathrm{~d})$ & $5.15(\mathrm{~d}, \mathrm{~J}=7.69,1 \mathrm{H})$ & $2^{\prime}$ & $133.0(\mathrm{~d})$ & $6.82(\mathrm{~d}, \mathrm{~J}=15.4,1 \mathrm{H})$ \\
14 & $84.9(\mathrm{~d})$ & $3.97(\mathrm{dd}, \mathrm{J}=7.70,8.42,1 \mathrm{H})$ & $3^{\prime}$ & $135.6(\mathrm{~d})$ & $7.31(\mathrm{~d}, \mathrm{~J}=15.4,1 \mathrm{H})$ \\
15 & $78.0(\mathrm{~d})$ & $5.11(\mathrm{~d}, \mathrm{~J}=8.43,1 \mathrm{H})$ & $4^{\prime}$ & $166.2(\mathrm{~s})$ & - \\
16 & $39.6(\mathrm{~d})$ & $2.13(\mathrm{~m}, 1 \mathrm{H})$ & $5^{\prime}$ & $71.5(\mathrm{t})$ & $3.63(\mathrm{~m}, 2 \mathrm{H})$ \\
17 & $78.4(\mathrm{~d})$ & $3.21(\mathrm{~m}, 1 \mathrm{H})$ & $6^{\prime}$ & $116.0(\mathrm{~s})$ & - \\
18 & $38.8(\mathrm{~d})$ & $1.60(\mathrm{~m}, 1 \mathrm{H})$ & $7^{\prime}$ & $127.0(\mathrm{~d})$ & $5.11(\mathrm{~d}, \mathrm{~J}=7.69,1 \mathrm{H})$ \\
19 & $104.2(\mathrm{~s})$ & - & $8^{\prime}$ & $30.8(\mathrm{t})$ & $1.29(\mathrm{~m}, 2 \mathrm{H})$ \\
20 & $36.7(\mathrm{t})$ & $1.59(\mathrm{~m}, 1 \mathrm{H})$, & $9^{\prime}$ & $165.4(\mathrm{~s})$ & - \\
& & $2.30(\mathrm{dd}, \mathrm{J}=4.77,13.2,1 \mathrm{H})$ & $2-\mathrm{OMe}$ & $60.6(\mathrm{q})$ & $3.65(\mathrm{~s}, 3 \mathrm{H})$ \\
21 & $76.3(\mathrm{~d})$ & $4.98(\mathrm{td}, \mathrm{J}=5.87,10.6,1 \mathrm{H})$ & $14-\mathrm{OMe}$ & $56.0(\mathrm{q})$ & $3.24(\mathrm{~s}, 3 \mathrm{H})$ \\
22 & $40.7(\mathrm{~d})$ & $2.02(\mathrm{~m}, 1 \mathrm{H})$ & $19-\mathrm{OMe}$ & $56.0(\mathrm{q})$ & $3.31(\mathrm{~s}, 3 \mathrm{H})$ \\
& & & & \\
\hline
\end{tabular}

Fig. 3. Partial structure of $\mathrm{AH}-758$ deduced from ${ }^{1} \mathrm{H}-{ }^{1} \mathrm{H}$ COSY and ${ }^{13} \mathrm{C}-{ }^{1} \mathrm{H}$ COSY experiments.

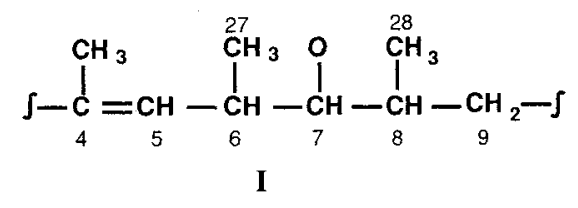<smiles>COC(C=CC=C(C)I)C(=O)I</smiles><smiles>CC(I)C(O)C(C)I</smiles>

$$
\underset{2^{\prime}}{\int-\underset{3^{\prime}}{\mathrm{C}}} \underset{ }{\mathrm{C}}=\mathrm{H}-\mathrm{S}
$$

which coupled to the unequivalent methylene protons at $\delta_{\mathrm{H}} 1.59$ and $2.30(20-\mathrm{H})$, and through $\delta_{\mathrm{H}} 2.02(\mathrm{H}-24)$ to $\delta_{\mathrm{H}} 0.92(25-\mathrm{H}), 1.05(33-\mathrm{H})$. The signals at $\mathrm{H}-22$ and H-24 showed same chemical shifts in the ${ }^{1} \mathrm{H}$ NMR spectrum. They showed correlation with the signal at $\delta_{\mathrm{C}}$ 40.7 and 29.6, respectively, in the ${ }^{1} \mathrm{H}^{-13} \mathrm{C}$ COSY spectrum. The partial structures $\mathrm{V}$ and VI were deduced in the same way.

The EI-MS of AH-758 showed fragment ion peaks similar to those of bafilomycins ${ }^{7)}$ and in the ${ }^{13} \mathrm{C}$ NMR spectrum the signals of $\mathrm{AH}-758$ from $\mathrm{C}-1$ to $\mathrm{C}-33$ were

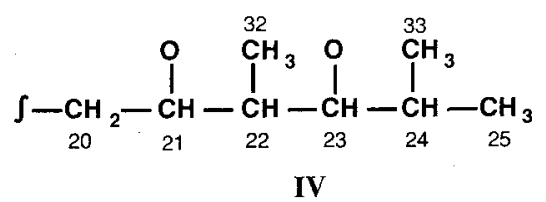

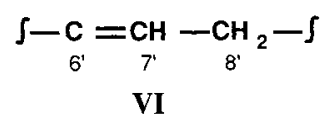

assigned by comparing with those of bafilomycins derived from 16-membered lactone ring and 6-membered hemiketal ring ${ }^{8}$.

The bafilomycins consisted of ten types derivatives differing from the substituents at C-7, C-19 or C-217). AH-758 was deduced as a $\mathrm{C}-21$ substituted derivative of bafilomycin $\mathrm{B}_{2}$.

The residual carbon signals were assigned as follows. In the ${ }^{13} \mathrm{C}$ NMR spectrum carbonyl signal at $\delta_{\mathrm{C}} 166.2$ showed higher intensity than that of $\delta_{\mathrm{C}}$ 165.4. This fact may be explained by the presense of two carbons having 
Fig. 4. Proposed structure of AH-758.<smiles></smiles>

same structure. The carbon signals at $\delta_{\mathrm{C}} 166.2\left(\mathrm{C}-1^{\prime}\right)$, $133.0\left(\mathrm{C}-2^{\prime}\right), 135.6\left(\mathrm{C}-3^{\prime}\right)$ and $166.2\left(\mathrm{C}-4^{\prime}\right)$ were assigned to fumarylester, which supported by the partial structure $\mathrm{V}$ (Fig. 3). An oxymethylene signal at $\delta_{\mathrm{H}} 3.63\left(\mathrm{H}-5^{\prime}\right)$, which showed the correlation with a signal at $\delta_{\mathrm{C}} 71.5$ $\left(\mathrm{C}-5^{\prime}\right)$ in the ${ }^{1} \mathrm{H}^{-13} \mathrm{C}$ COSY spectrum, showed no correlation with the other signals in ${ }^{1} \mathrm{H}^{-1} \mathrm{H}$ COSY spectrum. Taking into consideration of the partial structure VI (Fig. 3), a carbon signal at $\delta_{\mathrm{C}} 165.4$ (C-9') and a residual formula $-\mathrm{NH}$, the $\mathrm{C}-21$ substituent was elucidated as $3^{\prime}-\left(5^{\prime \prime}\right.$-oxo-2"-pyrrolin-2"-yl)methyloxycarbonyl acryloyl, commonly named as (5-oxo-2-pyrrolin2-yl)methyl fumarate, which supported by the fragment ion peak at $m / z 211$ in the EI-MS.

From the results described above, the structure of AH-758 was determined as shown in Fig. 4.

\section{Antiviral Activities}

AH-758 showed the antiherpetic activity of $0.09 \mu \mathrm{g} / \mathrm{ml}$ as $\mathrm{EC}_{50}$ against $\mathrm{HSV}-1$, and cytotoxicity of $1.3 \mu \mathrm{g} / \mathrm{ml}$ as $\mathrm{IC}_{50}$ against Vero cells. Therefore the selectivity (the ratio of $\mathrm{IC}_{50}$ to $\mathrm{EC}_{50}$ ) of $\mathrm{AH}-758$ was calculated as 14.4. The effects of $\mathrm{AH}-758$ on other viruses such as human cytomegalovirus, influenza virus and respiratory syncytial virus were examined. AH-758 strongly inhibited proliferation of human cytomegalovirus at the lowest concentration of the range tested $(0.5 \mathrm{ng} / \mathrm{ml})$ without cytotoxicity. AH-758 indicated 50\% inhibition against influenza virus and respiratory syncytial virus at 1.6 and $2.8 \mathrm{ng} / \mathrm{ml}$, respectively. Interestingly, AH-758 inhibited both DNA virus and RNA virus without viral selectivity.

\section{Antimicrobial Activities}

AH-758 indicated the weakly inhibitory activities ( $20 \mu \mathrm{g} / \mathrm{ml}$ as MIC) against Gram-positive bacteria such as Bacillus subtilis, Staphylococcus aureus, Micrococcus luteus. Gram-negative bacteria seemed to be insensitive. It showed rather strong antifungal activity against Saccharomyces cerevisiae (MIC, $<0.1 \mu \mathrm{g} / \mathrm{ml}$ ) and Aspergillus niger (MIC, $0.5 \mu \mathrm{g} / \mathrm{ml}$ ). The antimicrobial activities of AH-758 were similar to those of bafilomycins ${ }^{7}$.

\section{Acknowledgment}

We thank The Chemo-Sero-Therapeutic Research Institute for the supply of HSV, Vero cells with technical assistance of a part of this work.

\section{References}

1) Shirling, E. B. \& D. Gottlieb: Methods for characterization of Streptomyces species. Int. J. Syst. Bacteriol. 16: 313 340, 1966

2) Waksman, S. A.: The actinomycetes. Classification, identification and descriptions of genera and species. Volume 2. Williams \&Wilkins, Baltimore, 1961

3) Pridham, T. G. \& D. Gottlieb: The utilization of carbon compounds by some Actinomycetales as an aid for species determination. J. Bacteriol. 56: 107 114, 1948

4) Schinazi, R. F.; J. Peters, C. C. Williams, D. Chance \& A. J. NAHMIAS: Effect of combinations of acyclovir with vidarabine or its $5^{\prime}$-monophosphate on herpes simplex viruses in cell culture and in mice. Antimicrob. Agent. Chemother. 22: 499 507, 1982

5) Boyd, M. R.; T. H. Bacon, D. Sutton \& M. Cole: Antiherpesvirus activity of 9-(4-hydroxy-3-hydroxymethylbut-1-yl)guanine (BRL39123) in cell culture. Antimicrob. Agents Chemother. 31: $1238 \sim 1242,1987$

6) Buchanam, R. E. \& N. E. GibBons: Bergey's Manual of Determinative Bacteriology. Volume 8th ed., Williams \& Wilkins, Baltimore, 1974

7) Werner, G.; H. Hagenmaier, H. Drautz, A. BaumGARTNER \& H. Z̈̈HNER: Metabolic products of microorganisms. 224. Bafilomycin, a new group of macrolide antibiotics. J. Antibiotics 37: 110 117, 1984

8) Werner, G.; H. Hagenmaier, K. Albert, H. Kohlshorn \& H. Drautz: The structure of the bafilomycins, a new group of macrolide antibiotics. Tetrahedron Lett. 24: $5193 \sim 5196,1983$ 